\title{
Promoting Landscape-Level Forest Management in Fire-Prone Areas: Delegate Management to a Multi-Owner Collaborative, Rent the Land, or Just Sell It?
}

\author{
Ana Martins *(i), Ana Novais, José Lima Santos and Maria João Canadas (i) \\ Centro de Estudos Florestais, Instituto Superior de Agronomia, Universidade de Lisboa, Tapada da Ajuda, \\ 1349-017 Lisboa, Portugal; ananovais@isa.ulisboa.pt (A.N.); jlsantos@isa.ulisboa.pt (J.L.S.); \\ mjcanadas@isa.ulisboa.pt (M.J.C.) \\ * Correspondence: anacostamartins@gmail.com
}

Citation: Martins, A.; Novais, A.; Santos, J.L.; Canadas, M.J. Promoting Landscape-Level Forest Management in Fire-Prone Areas: Delegate

Management to a Multi-Owner Collaborative, Rent the Land, or Just Sell It? Forests 2022, 13, 22. https:/ / doi.org/10.3390/f13010022 Academic Editor: José M.C. Pereira

Received: 19 November 2021 Accepted: 20 December 2021 Published: 24 December 2021

Publisher's Note: MDPI stays neutral with regard to jurisdictional claims in published maps and institutional affiliations.

Copyright: (C) 2021 by the authors. Licensee MDPI, Basel, Switzerland. This article is an open access article distributed under the terms and conditions of the Creative Commons Attribution (CC BY) license (https:// creativecommons.org/licenses/by/ $4.0 /)$.

\begin{abstract}
Forest management at the landscape level is a requirement for reducing wildfire hazard. In contexts where non-industrial private forest ownership prevails, the collaboration among multiple owners has been proposed as the way forward to reach consistent fuel management at that level. The current literature has been focused on identifying the factors that lead to collaboration among owners. In this study we explored other ways to reach landscape-level management in addition to the collaborative way, such as those that may be promoted through land renting or selling. Different contexts and owner types may require different solutions. Thus, we explicitly asked which alternative would be chosen by a given forest owner, from the following set: keeping individual management, entering a multi-owner collaborative arrangement where they delegate management, renting to a pulp company; or selling the land. In a context of small-scale ownership and high recurrence of wildfires in Portugal, a face-to-face survey was carried out to a sample of landowners. Our results suggest that there is not an a priori generalized unwillingness of owners to delegate management, rent or sell the land and thus they seem prone to align themselves with policy strategies to promote management at the landscape level. Multinomial logit regression modelling allowed us to explain and predict owners' choices among the aforementioned set of alternative management options. We found that choosing multi-ownership collaboration, as opposed to keeping current individual management, is associated with passive management under harsher conditions, by non-residents without bonding capital. The identified factors of owners' choices show the limited scope of tenancy and land-market mechanisms to promote landscape-level management. The best policy option was found to depend on the owner profiles prevailing in the target area. This suggests that studying the existing context and owner types is required to design effective policies.
\end{abstract}

Keywords: multi-ownership collaboration; management delegation; land market; structural adjustment; policy strategies; wildfires

\section{Introduction}

The current trend of increasingly frequent wildfires calls for fuel management at the landscape level [1,2]. Meaningful reduction of wildfire hazard requires reducing the continuity of fuels, through e.g., thinning or understory shrub clearing; isolating fuels, through e.g., networks of fuel breaks, or mosaics with different land uses; and converting stands to less flammable tree species [2]. To be effective, these interventions need to be coherently implemented at the landscape level, for two main reasons. First, due to the nonlinear character of the relationship between hazard and managed area $[3,4]$, management is required to cover a minimum threshold area within the landscape. Second, space matters in the application of fuel management techniques, in particular as regards fuel isolation or stand conversion; these actions need to take place at specific locations. This requires the development and implementation of a management plan at the landscape level. 
In contexts where non-industrial private forest (NIPF) owners prevail, uncoordinated individual management effort may be insufficient to achieve the aforementioned threshold and location-specific requirements. The coordination of numerous landowners becomes an even greater challenge in very-small-scale ownership contexts, as in a considerable part of Portuguese forest areas [5-8].

The collaboration among owners is the most often proposed strategy to promote landscape-level management [9-13]. Nonetheless, in small-scale ownership contexts, structural adjustment, i.e., the reduction of the total number of private owners and increase in ownership size is often assumed as desirable, but seldom explicitly addressed in the policy literature aimed at promoting landscape-level management. In fact, that adjustment is expected to happen under strictly market mechanisms and the few policies in place in several European countries intend to prevent further fragmentation rather than actively promoting structural adjustment $[7,14]$.

Owners' enrollment in collaborative arrangements may prove insufficient to achieve landscape-level management if it stops in the design and approval of a common forest management plan that is not jointly implemented [4]. This seems to be the case in Portugal, where policy-promoted multi-ownership collaboration under the Forest Intervention Zone (FIZ) arrangement, since the aftermath of the huge wildfires of 2003 and 2005, is currently under scrutiny considering FIZs delay in the implementation of the respective management plans. In fact, in the public and policy debate, the FIZ solution is considered as simply one among several other alternatives, including structural adjustment [8].

The mainstream literature on private forest owners and landscape-level management is focused on studying owners' preferences towards collaboration. The policy problem of choosing among different solutions to promote landscape-level management led us, in this study, to go beyond this literature, by explicitly analyzing owners' choices between multiownership collaboration and other possible routes to deliver the desired landscape-level management, namely the transfer of land rights to others either temporarily (land renting) or permanently (land selling).

This study aims to explore owners' responses to alternative ways to achieve management at the landscape level, while adding land transfer options to collaboration among owners, which opens up the range of possible solutions. Our hypothesis is that the best policy alternative to promote landscape-level management depends on the local pattern of owner profiles.

\section{Literature Review and Analytical Framework}

The presentation of our analytical framework begins with the consideration of both collaborative and non-collaborative routes towards landscape-level management, through a brief literature review of coordination modalities to locate the FIZ case. The literaturebased identification of the owner-level factors favoring their choice of collaborative and non-collaborative alternatives completes the description of our framework. A separate subsection defining the three specific objectives of the study follows.

\subsection{Modalities of Multi-Ownership Coordination and the Portuguese Forest Intervention Zones}

Successful examples of collaboration among NIPF owners have been reported as concerns information, equipment or financial aspects [12]. However, integrated management decisions, as the object of collaboration, are uncommon or occur only in small groups [12,13,15-18]. In fact, this last type of multi-ownership collaboration is more demanding, as it involves the spatial and temporal coordination of decisions across multiple property boundaries.

Three modalities of coordination have been described according to the nature of the coordinator and the degree of formalization. First, informal agreements between multiple owners are characterized by self-organization coexisting with independent management of individual property. Second, some formal agreements require the creation of an organization for the purpose of coordination, e.g., associations or cooperatives, as well as 
the Portuguese FIZ. Third, other formal agreements involve a third-party organization acting as the coordinator, e.g., an NGO, a governmental institution, forester, contractor, or forest corporation $[15,18,19]$. In the first two modalities, forest owners are collectively involved in formal or informal decision-making, under certain governance rules, third-party coordination may not require direct collaboration between NIPF owners.

Created in 2005 to increase the fire-resilience of Portuguese territories, FIZ correspond to governmental legislation promoting voluntary enrolment in formal private multiownership and cross-boundary collaboration. Each FIZ corresponds to a contiguous minimum surface and a minimum number of enrolled owners $[4,8,20]$. Coordination decisions are the competence of the FIZ's managing body (e.g., forest owners association), which is responsible for designing a single forest management plan for the whole area, which is first approved by the Owners' Assembly and then submitted to approval by the National Forest Authority. This plan includes and maps fuel breaks, water points and other collective infrastructures, as well as stand-level constraints on forest management by owners (species, interventions). According to the FIZ legislation, once approved, the plan is supposedly mandatory for all owners, including those who are not FIZ members but have their land within FIZ boundaries. Despite this strong legal status of the FIZ and its forest management plan, the implementation of the plan is not ensured, as it requires costly interventions to build and maintain collective infrastructure, convert stands to less fire-prone species and promote active fuel management at the stand level $[4,20]$. This implementation failure is related to the facts that (1) mechanisms for the public funding of these costs are not fully developed and (2) delegating management by owners to the FIZ managing body is not mandatory and seldom adopted. Management delegation has been considered crucial for the full implementation of the forest management plan of the FIZ [20] because it requires consistent and synchronized interventions, typically across hundreds of owners and often requires a common application for funding those interventions. Imposing management delegation by law, especially for non-members, would raise legal problems as regards property rights and this may explain why it is not in the FIZ law. A solution based on public funding to support the buying of management delegation by the FIZ managing body could help solving this problem.

\subsection{Owners' Choices among Alternative Management Options}

Besides owners' collaboration, other distinct policy strategies to promote or favor landscape-level management may be considered, which requires broadening the choice set for owners, including other alternatives rather than management delegation to the FIZ (Figure 1). In contexts of small-scale ownership dominance, a quite distinct policy option is structural adjustment. This adjustment requires the full transfer of property rights in the land market by the small and very small owner, i.e., land selling. There is, however, an intermediate policy option to favor landscape management that consists in the promotion of temporary transfer of land use rights through renting (contractual arrangements in the tenancy market) by small and very small owners; in this case, the tenant organization may be viewed as acting as a third-party coordinator [3].

Despite the importance given to forest ownership dynamics and, in particular, the fear that ownership is split in inheritance processes, in particular close to urban areas $[6,7,14]$, land transfers have not yet been included in studies of owners' preferences related to different alternatives for achieving landscape-level management. However, the influence of the institutional characteristics of arrangements, such as the length of commitments, the nature of the entity who leads the process, the extent of management delegation to that entity, the financial cost or benefit for the owner and the resulting perception of autonomy and decision control over their land, to explain the participation in multi-ownership collaboration, as recognized in the literature $[10,11,13,16,20-27]$, has been a source of inspiration to build up the conceptual framework for comparing within the broader range of alternatives explored in this study. 


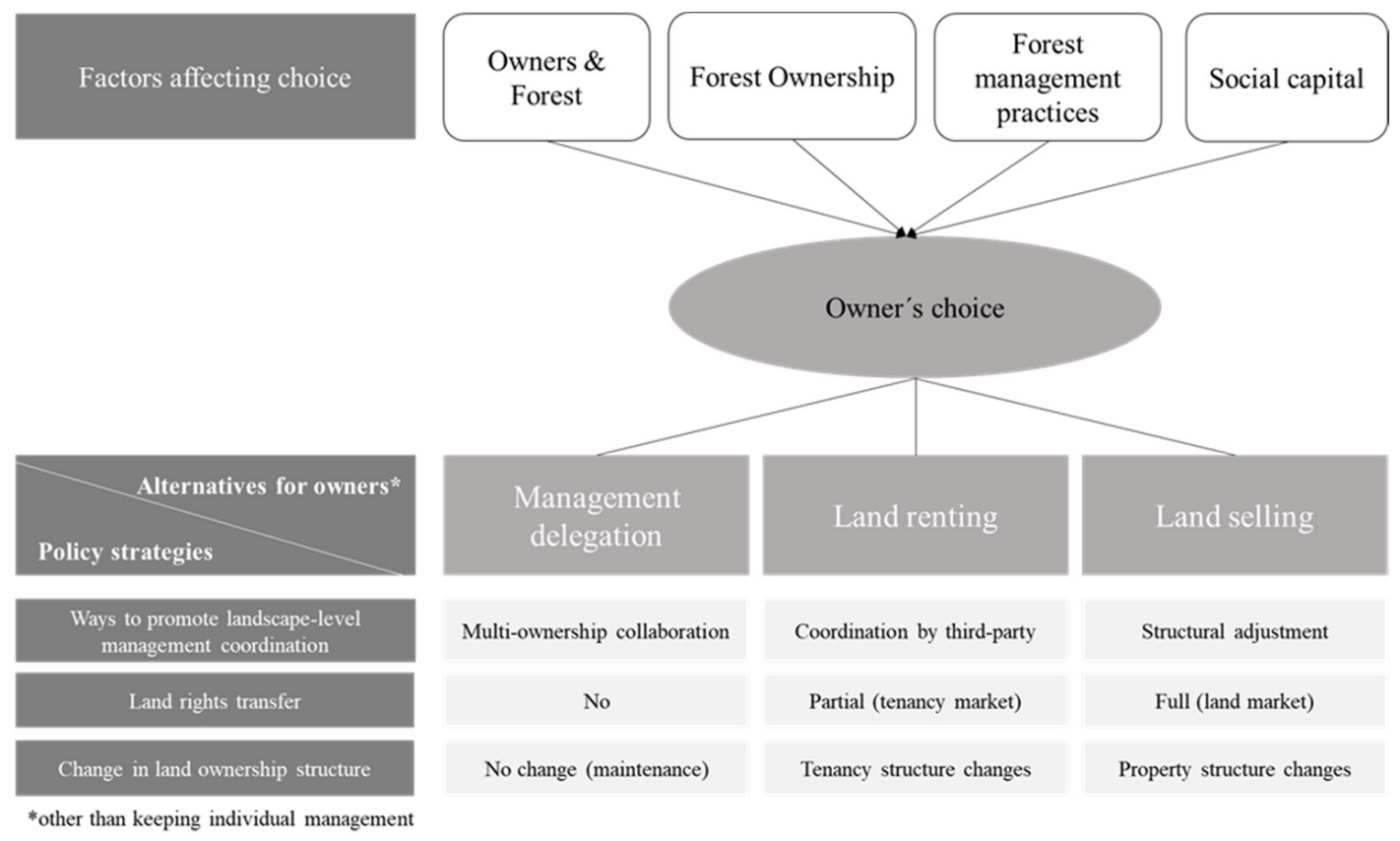

Figure 1. Owners' choices among alternative management options-an analytical framework.

In order to identify the factors explaining the choice by owners between those alternatives, which are in line with different policy strategies to favor landscape-level management (multi-ownership collaboration, partial property rights transfer/coordination by third-party and full property rights transfer), we resorted to a review of (1) the literature on forest owners' collaboration $[10,11,14,15,18,19,21,22,24,26-29]$ and (2) the more general literature on NIPF owners' management [30-33]. This review was aimed at identifying owner-level factors that may explain and help predicting the choices made by different types of owners, with different rationalities or decision logics, which will help selecting the policy strategy to promote landscape-level fuel management best fitting the prevailing owner profiles in a specific area.

\subsection{Owner-Level Factors Explaining Their Choices between Alternative Management Options}

From the aforementioned review, possible owner-level factors for explaining owner choices have been grouped in four main dimensions: the owner's sociodemographic attributes and relationship with the forest, forest ownership characteristics, current management practices and social capital (Figure 1).

The owner's socioeconomic characteristics (such as age, education, place of residence or income level) are often considered in the analysis of owners' collaboration, since they are supposed to influence knowledge, beliefs and personal attitudes towards collaboration goals and its effectiveness [10,27], or individualism and opportunistic behavior $[3,12,34,35]$. Nonetheless, their influence does not always go in the same direction. The owner's experience of exceptional or uncertain catastrophic events such as wildfires is often viewed as a trigger to collaboration [12] but can also decisively encourage a shift from individual management to some level of land rights transfer by land renting or selling.

Forest ownership size is an almost unavoidable variable in any analysis of owners management choices $[7,28,30,36]$, the same applying when willingness to enroll or actual enrollment in collaborative arrangements is at stake [10,11,27]. Ownership size is often considered as a proxy for owner's management goals and constraints (namely on the grounds of economies of scale) and thus there is a widely held assumption linking smallscale property to the absence of both active management and willingness to cooperate or coordinate [34]. Nonetheless, ownership size is not always found to be a relevant variable to explain coordination choices $[10,11,19,27]$. 
The owner's management of their woods can be characterized in very different ways, from levels of intensity (as the abovementioned active/passive gradient) to the existence of a management plan, or motivation to care for their forest. Absence of this plan or merely lack of interest, absenteeism or abandonment are often considered as reasons for lower involvement in multi-ownership collaboration $[10,11,13,21,22,24]$. Forest management practices, including the identification of the interventions carried out, labor source (family or wage labor, outsourcing) and the technique used, are less explored in these studies as factors for collaboration $[10,12,19,26]$, yet they may prove to be better indicators of owners management logics and intentions [31,33].

Social capital, i.e., shared cognition, trust and norms of reciprocity, sense of group identity and networking, is expected to promote cooperation among private owners $[3,13,35]$. Therefore, shared cognition (inter-knowledge, information sharing), trust instead of conflict and membership of formal or informal associations are expected to favor the choice of management delegation under FIZ collaboration rather than individualized management and land renting or selling $[18,23,29,37]$.

In sum, in contexts of small-scale ownership and rural decline prevalence, one may expect that owners more active in forest management (carrying out more silvicultural interventions and investments), more directly involved in that management (namely with family work versus outsourcing), with larger ownership size and having acquired land by purchase instead of inheritance alone $[10,12,14,16,30,31,37]$, may be less prone to rent or sell their land. On the contrary, being retired, older, non-resident (place of primary residence relative to the forest property) and with other sources of income beyond farm and forest activities, is expected to favor the full transfer of property rights $[14,33]$.

\subsection{Objectives}

The overall goal of this study is to explore owners' responses to alternative ways to achieve coherent fuel management at the landscape level, in addition to multi-owner collaboration, in order to broaden the range of possible policy solutions.

Because owners are often seen as unwilling to collaborate or transfer their land, our first specific objective is to assess the proportion of owners who prefer each of these alternative options for managing their forest land in the future: keeping the current individual management, delegating management in a FIZ, renting and selling the land. By contrast with the first option, the other three can be seen as a way towards landscape-level management.

As different contexts, namely owner-type composition, may require different solutions, our second specific objective is understanding whether and why different owners choose different options. From the literature review, possible factors for explaining landowner choices can be grouped in several dimensions, such as owner and ownership characteristics, management practices and social capital. This study also innovates by widening the range of usual factors and comparing the relative effect of each of these dimensions on owners' choices.

A third specific objective is using our understanding of the particular choices of different owners to predict how specific owner profiles may react to alternative coordination solutions.

\section{Methods}

\subsection{Case Study}

Our study setting is a parish in the Centre of Portugal, Alvares (Góis municipality), where a group of forest owners were establishing a FIZ as a response to the particularly violent wildfires in 2017 [38]. In the last 40 years, more than 20,000 hectares, twice the area of the parish, had been burnt in a total of 42 wildfires [39]. The parish is characterized by very steep hillsides, a Mediterranean climate, forests covering more than $90 \%$ of the land, which are dominated by eucalyptus (53\%) and pine (30\%) plantations for wood production. It is one of the most wildfire-susceptible areas in Portugal [40]. The forest owner's active involvement in forest management at the landscape scale was seen as key for effective 
wildfire-hazard reduction. In this context, we collected NIPF owners' views on forest management options for wildfire-hazard reduction.

Most of the forest area (84\%) is under NIPF ownership. The two paper pulp companies operating in the parish manage $16 \%$ of the forest, $6 \%$ of which is rented from the NIPF owners. The property structure is unequal and concentrated: small owners (with an area of less than 5 hectares) represent $87 \%$ of the total forest owners of the parish, but they hold less than one third of the area. More than half of the area belongs to $6 \%$ of the owners who have more than 10 hectares. Another feature of the property structure is its high fragmentation: on average, an owner has 3 hectares in 6 parcels, with 0.5 hectares each. Most of the area $(61 \%)$ belongs to owners who live outside the municipality.

\subsection{Survey and Owner Characterization}

Between March and May 2018, we conducted a face-to-face survey of NIPF owners in Alvares, including both local and non-local residents, the latter living in urban areas in Lisbon and Coimbra. In the absence of a land registry for this region, we were supported by the local forest owner's association, the parish council and the founding group of the FIZ, in identifying and reaching potential respondents. From the full list of the forest owners with more than 1 hectares provided by the founding group of the FIZ, a random set of 400 owners was first contacted by letter or phone call. To increase the size of the sample and provide the full coverage of all owner types (e.g., more/less active, resident/non-resident in Alvares), this set of respondents was complemented using the snowball method. As a result, 221 interviews were completed.

Our sample may have a certain bias towards owners with similar characteristics to those who are closer to those entities that supported us. This bias may affect statistical inference, e.g., when estimating the shares of the owner population preferring a certain management option, but not so much in the estimation of the model parameters that reflect how the owners' attributes affect their choices.

The questionnaire was structured to study the constraints and options faced by forest landowners for managing their forest areas to reduce the risk of wildfires, which provided the context for owners to choose their preferred land management alternative in the future. The results of these hypothetical choices were used to build our dependent variable, as detailed in Section 2.3.

Table 1 provides a summary description of owners in our sample. Owners are mainly men $(75 \%)$, more than 65 years old $(54 \%)$, mostly without a college degree $(75 \%)$ and retired (52\%) (Table 2). Most are non-residents, i.e., their primary home is outside the municipality, although they often keep an inherited family second home at the parish. Their main source of income besides the forest is related to an activity in the primary sector, retirement or other pensions, savings or rents $(69 \%)$. When asked about the importance of the forest for them, only 39\% indicated forest income as being one of the reasons for owning forest land. Almost all owners were affected by the 2017 wildfires.

The majority $(54 \%)$ of our respondents own $>4$ ha of forest. The average property size is 15 ha, scattered by 13 parcels, with an average of 1.13 ha each. Almost $3 / 4$ of the respondents had eucalyptus, pine or mixed pine and eucalyptus stands.

Most owners (81\%) harvested their forest stands for wood in the last 10 years or since they became responsible for ownership. In the same period, the three most frequent types of productive interventions carried out were shrub clearing (65\% of owners), thinning and poles selection (48\%) and pruning (37\%). At least $46 \%$ of the respondents carried out at least one type of investment in their forest stands.

Most owners are members of at least one association of several types, including local cultural associations, which reinforce intra-community ties and other associations with economic, technical or other external representation purposes such as linking with public authorities. Although living mostly outside the municipality, more than $3 / 4$ of the owners know the majority of adjacent owners. However, there is a lack of exchange of 
price information and many do not consider it easy to enter into an agreement for jointly executing or contracting forest operations.

Table 1. Summary description of owners (number and \% of respondents, total $=221$ ).

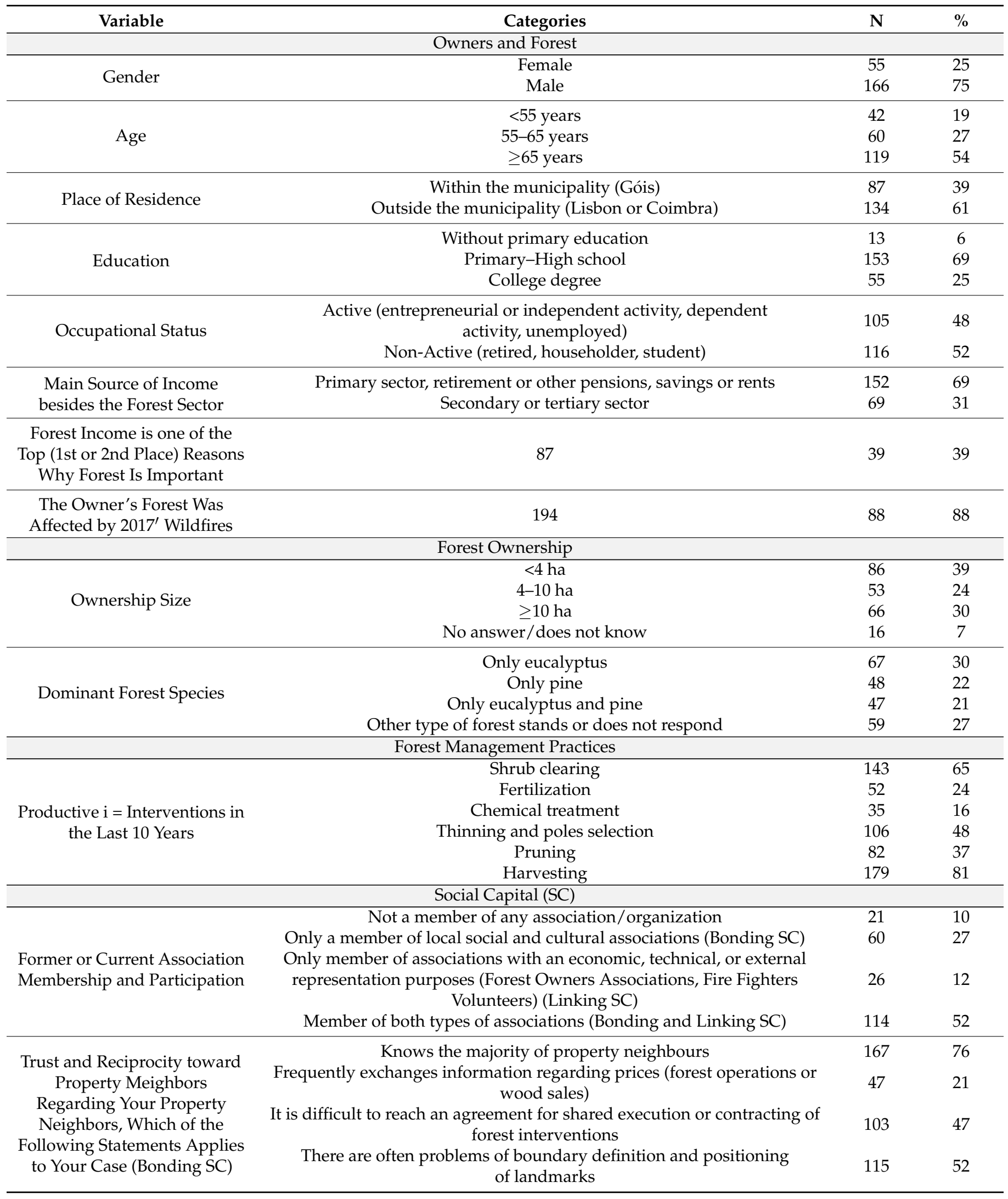


Table 2. Description of independent variables.

\begin{tabular}{|c|c|c|c|c|c|}
\hline \multirow[b]{2}{*}{ Dimension } & \multirow[b]{2}{*}{ Variable } & \multirow[b]{2}{*}{ Description } & \multicolumn{3}{|c|}{ Respondents } \\
\hline & & & $\mathbf{N}$ & $\begin{array}{c}\text { Mean or } \\
\text { Percentage }\end{array}$ & $\begin{array}{l}\text { Standard } \\
\text { Deviation }\end{array}$ \\
\hline \multirow{7}{*}{$\begin{array}{l}\text { Owners and } \\
\text { Forest }[\mathrm{OF}]\end{array}$} & Non-resident & $\begin{array}{l}\text { Primary home (residence) outside the } \\
\text { municipality of Góis, i.e., Lisbon or Coimbra }\end{array}$ & 134 & 61 & - \\
\hline & $\begin{array}{l}\text { Non-primary sector } \\
\text { income }^{* *}\end{array}$ & $\begin{array}{c}\text { Main source of income comes from wages or } \\
\text { independent activity in the secondary or } \\
\text { tertiary sectors }\end{array}$ & 69 & 31 & - \\
\hline & Female ** & Female gender & 55 & 25 & - \\
\hline & Retired ** & The owner is retired, or householder & 116 & 53 & - \\
\hline & $\begin{array}{l}\text { No contribution from } \\
\text { forest revenue ** }\end{array}$ & $\begin{array}{l}0 \% \text { weight of forest revenue on the household } \\
\text { income, over the last } 10 \text { years }\end{array}$ & 102 & 46 & - \\
\hline & Age * & Age of the owner & - & 65 & 12 \\
\hline & Education * & With a college degree or above & 55 & 25 & - \\
\hline \multirow{5}{*}{$\begin{array}{l}\text { Forest } \\
\text { Ownership } \\
\text { [FO] }\end{array}$} & Inherited land alone & Ownership acquired only by inheritance & 139 & 63 & - \\
\hline & Forest renting & $\begin{array}{l}\text { Past or current experience of renting to a pulp } \\
\text { paper company or forest contractor }\end{array}$ & 23 & 10 & - \\
\hline & Ownership size * & Total area (ha) owned & - & 15.4 & 35.5 \\
\hline & $\begin{array}{l}\text { Ownership size } \\
>10 \text { ha }^{*}\end{array}$ & $\begin{array}{l}\text { Total owned land area above } 10 \text { ha (including } \\
\text { any land parcel rented to others) }\end{array}$ & 66 & 29.9 & - \\
\hline & Ownership size $>4$ ha * & Total owned land area above 4 ha (idem) & 119 & 54 & - \\
\hline \multirow{5}{*}{$\begin{array}{c}\text { Forest } \\
\text { Management } \\
\text { Practices [FMP] }\end{array}$} & $\begin{array}{l}\text { Last plantation after } \\
1998^{* *}\end{array}$ & $\begin{array}{l}\text { Having planted or replanted forest over the last } \\
\qquad 20 \text { years }\end{array}$ & 102 & 46 & - \\
\hline & $\begin{array}{l}\text { At least one } \\
\text { productive } \\
\text { intervention }(\mathrm{PI})\end{array}$ & $\begin{array}{c}\text { Having performed at least one of the following } \\
\text { PI: shrub clearing, fertilization, chemical } \\
\text { treatments, thinning, poles selection } \\
\text { and pruning. }\end{array}$ & 166 & 75 & - \\
\hline & Investments ** & $\begin{array}{l}\text { Number of types of investments from the } \\
\text { following list: plantation and densification; road } \\
\text { construction or improvement, fuel breaks; water } \\
\text { points; equipment. }\end{array}$ & - & 0.5 & 0.9 \\
\hline & Family work ** & Executes PI and only uses family work & 58 & 26 & - \\
\hline & Manual work & $\begin{array}{l}\text { Executes PI and only uses manual or } \\
\text { mechanically assisted work }\end{array}$ & 127 & 58 & - \\
\hline \multirow{3}{*}{$\begin{array}{l}\text { Social Capital } \\
\quad[\mathrm{SC}]\end{array}$} & $\begin{array}{l}\text { Frequent information } \\
\text { exchange }\end{array}$ & $\begin{array}{l}\text { The owner perceives "Frequent information } \\
\text { exchange among her/his property } \\
\text { neighbourhood regarding prices (work/tasks or } \\
\text { wood selling)" }\end{array}$ & 47 & 21 & - \\
\hline & $\begin{array}{l}\text { Easy agreements } \\
\text { with neighbours }\end{array}$ & $\begin{array}{c}\text { The owner contradicts "Difficult agreements for } \\
\text { shared execution or contracting of forest } \\
\text { operations among her/his } \\
\text { property neighbourhood" }\end{array}$ & 117 & 53 & - \\
\hline & $\begin{array}{l}\text { Membership of local } \\
\text { associations alone }\end{array}$ & $\begin{array}{l}\text { Former or current membership of one or more } \\
\text { social and cultural associations: village } \\
\text { improvement committee, municipal house of } \\
\text { Góis, festivity committee; sports / cultural club. }\end{array}$ & 60 & 27 & - \\
\hline
\end{tabular}

* Variable dropped, as non-significant in partial models; ** Variable dropped, as non-significant in the final model (while significant in a partial model).

\subsection{Dependent and Independent Variables}

To model owners' choices for the future management of their forestland, a categorical dependent variable was built from the replies of our respondents to a single question regarding their preferred alternative (only one) among four options (Table 2): (a) Individually managing the land; (b) Delegating management to a FIZ; (c) Land renting to a pulp company for a good price and (d) Land selling for a good price. Option (a) represents the maintenance of the current situation. Options (b) and (c) correspond to different coordination 
modalities: multi-owner collaboration and formal third-party coordination, respectively. Selling the property, option (d), would eventually lead to structural adjustment.

Possible explanatory variables were grouped in four dimensions: owners and forest, forest ownership, forest management practices and the owner's social capital (Table 2). The owner attributes and her/his relationship with the forest encompass the place of residence, main source of income besides forest, gender, whether he/she is active or not, the weight of forest revenue in household income, age and educational attainment. The forest ownership dimension includes structural ownership characteristics such as whether the land was acquired via inheritance or bought, previous experience with forest renting and size. Forest management practices refer to the operations carried out during the previous 10 years, including: plantations, productive interventions (PI), the number of investments and the workforce type and technique involved. Finally, the social capital (SC) dimension includes the following three variables: frequent information exchange among neighbours, easy agreements with neighbours and membership of local associations alone. The selection of these three variables, from the list of SC indicators available in the survey, took into consideration their frequency in the sample and the strength of their bivariate relationship with the dependent variable. All three variables refer to bonding SC, which concerns strong intracommunity ties, as opposed to bridging (inter-community ties) and linking (external vertical links with individuals or groups in places of power or authority) SC [37,41].

Except for the number of investments, ownership size and the owner's age, which are continuous, all the other are binary (yes/no) variables.

\subsection{Data Analysis}

Multinomial logit (MNL) regression was used to identify the variables that best explain the owners' preferred option among the four aforementioned management alternatives. This is an appropriate modelling approach given the categorical and non-ordered nature of the dependent variable. The alternative "individually manage the land" was set as the baseline category (in the sense of [42]), as it describes the current situation for all respondents.

Based on each respondent i's choice of management alternative $j(=1,2,3,4)$, that is $Y i=j$, the MNL model was specified as three equations, one for each alternative but the baseline category. Each equation has the following structure (Equation (1):

$$
\begin{gathered}
\log [(\operatorname{Prob}(Y i=j)) / \operatorname{Prob}(Y i=\text { baseline })]=\alpha+\beta j 1 X i 1+\beta j 2 X i 2+ \\
\beta j 3 X i 3+\ldots+\beta j k X i k+\varepsilon i j=Z i, j+\varepsilon i j
\end{gathered}
$$

where $\operatorname{Prob}(Y i=j)$ is the probability of forest owner $i$ choosing the management alternative $j, \operatorname{Prob}(Y i=$ baseline $)$ the probability choosing the baseline, $(X i 1, \ldots, X i k)$ is the vector of explanatory variables (or predictors) that may influence the choice of $\mathrm{j}$ made by owner $i$ and $(\alpha j, \beta j 1, \ldots, \beta j k)$ is the vector of parameters to be estimated. The random term $\varepsilon i j$ allows for the inclusion of effects that cannot be captured by the chosen predictors.

Maximum likelihood was used to estimate a parameter vector $(\alpha j, \beta j 1, \ldots, \beta j k)$ for each management alternative $\mathrm{j}$ but the baseline [43].

\subsubsection{Model Specification (Variables Selection)}

To explore the multivariate effects of the variables in Table 3, four partial models were first estimated, each with variables belonging to one single dimension. This exploratory, learning stage helped in selecting variables with a statistically significant coefficient at the $10 \%$ level. Using only these variables, a single model was then estimated which would potentially include variables in any of the four dimensions. To decide on the final specification of our model, we were guided by conceptual insights drawn from the literature review and used the $5 \%$ level of significance for variable selection and the Akaike information criterion (AIC) to assess overall goodness of fit. To check the reliability of our results, backward stepwise model estimation with all potential explanatory variables was also performed, so that we can check which results still hold when using a less conceptually guided approach. 
Table 3. Owners' choices between alternative management options (number and \% of respondents, total $=221$ )

\begin{tabular}{|c|c|c|c|}
\hline \multirow[b]{2}{*}{ Variable } & \multirow[b]{2}{*}{ Categories } & \multicolumn{2}{|c|}{ Respondents } \\
\hline & & $\mathbf{N}$ & $\%$ \\
\hline \multirow{4}{*}{$\begin{array}{c}\text { If you could choose, what } \\
\text { option, from the ones below, } \\
\text { would you prefer? }\end{array}$} & Individually managing the land & 72 & 33 \\
\hline & Delegating management to a Forest Intervention Zone (FIZ) & 86 & 39 \\
\hline & Land renting to a paper pulp company for a good price & 29 & 13 \\
\hline & Land selling for a good price & 34 & 15 \\
\hline
\end{tabular}

\subsubsection{Simulating Choices among Management Alternatives by Different Owners' Profiles}

The estimated final model was then used to predict the probability of choice of each management alternative $(\hat{p})$ by an owner with a particular profile, characterized his/her values for each of the explanatory variables in the final model: $(1, X i 1, X i 2, X i 3, \ldots, X i k)$. The owner profiles were set to explore the diversity and relevance of the explanatory variables with greater impact on choice, while ensuring they represent numerous sections within our sample.

The $Z i, j=(\alpha j, \beta j 1, \ldots, \beta j k) .(1, X i 1, X i 2, X i 3, \ldots, X i k)$ were estimated by multiplying the estimated parameter vector by the explanatory-variable vector corresponding to each particular owner's profile and introduced in the final MNL model to predict the mean probability of owners with that specific profile $i$ choosing each management alternative $j$ (Equations (3) and (4) (as in [43])). These mean probabilities and the corresponding 95\% confidence intervals were plotted for each profile and alternative.

$$
\begin{gathered}
\hat{p} Y i=\text { baseline }=1 /\left(1+\sum \exp (\overline{Z i, j})\right) \\
\hat{p} Y i=j=(\exp (\overline{Z i, j})) /\left(1+\sum \exp (\overline{Z i, j})\right)
\end{gathered}
$$

Model estimation and graph plotting were performed in SPSS version 25.

\section{Results}

After briefly describing owners' choices regarding alternative management options, we identify the factors explaining those choices based on the estimated final MNL model. Finally, simulations of choices between options are presented for different owners' profiles.

\subsection{Owners' Choices between Alternative Management Options}

Maintaining individual management, entering in a multi-owner collaborative arrangement where they delegate management, renting to a pulp company, or selling the land were the four alternative management options considered. Faced with the possibility of choosing between them, only a minority of owners in our sample (33\%) would choose to continue individually managing their land. A higher number of owners (39\%) would opt for delegating management to a FIZ, therefore admitting shifting from current individual management to collaborative management under FIZ coordination. Land selling and land renting to a paper pulp company were considered the preferred alternative by $15 \%$ and $13 \%$ of the owners, respectively. Overall, most of our respondents $(2 / 3)$ would choose not to continue managing the land individually.

\subsection{Factors Explaining Change from Current Individual Management to Alternative Options}

Our final MNL model (Table 4) retains only those independent variables whose effect on choices made by the respondents remained significant, even when in competition for explanatory capacity with variables from all the four dimensions. The less represented dimension in this model corresponds to the owners' socioeconomic characteristics (OF), with the place of residence as the only retained variable in this dimension; other variables from this dimension, such as age, gender, education, occupation status, source of income besides the importance of forest and forest income to the household income were not significant. The other three dimensions are represented in a more balanced way. 
Table 4. Multinomial logit (MNL) model of choices between management alternatives.

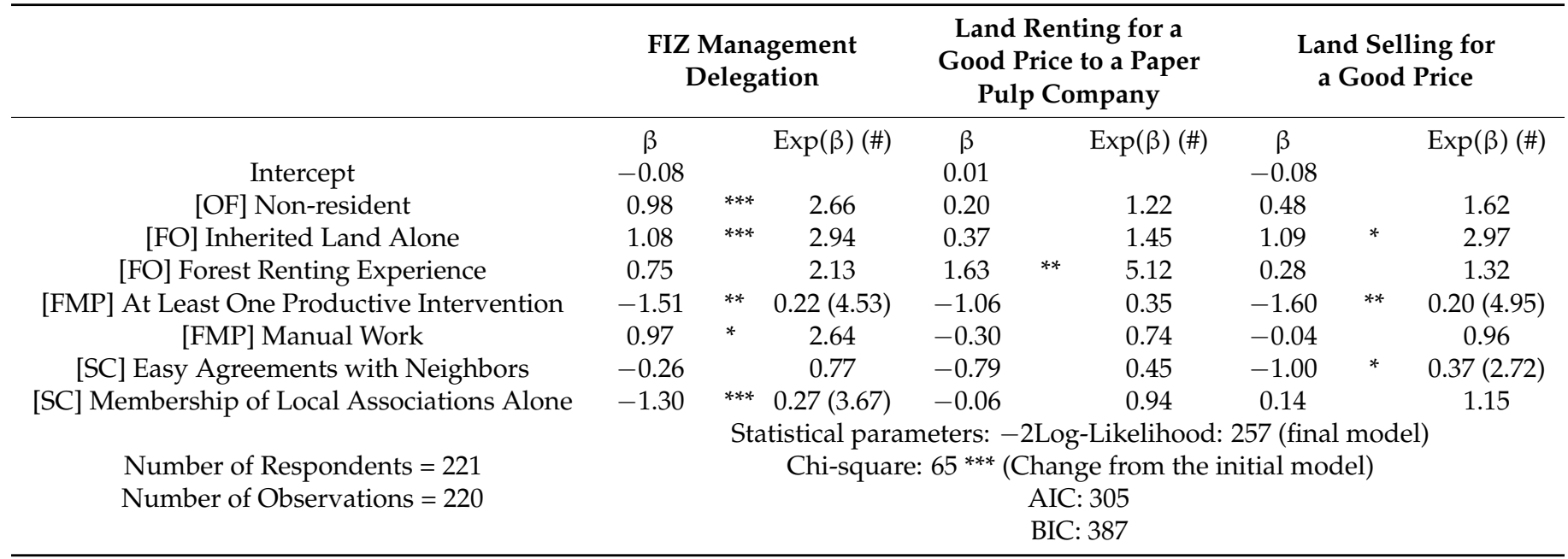

Note 1: The reference category is "Individually managing the land"; Note 2: Significant at $1 \%{ }^{* * *} ; 2.5 \%$ ** and $5 \%$ * Note 3: (\#) for readability purposes in the case of significant negative Exp $(\beta)$ values we also present in brackets the equivalent odd ratio value for the inverse of the variable, as it would have a positive (influencing factor) effect.

Focusing on the choice of collaboration under FIZ with management delegation, the relative probability of choosing this alternative over the baseline is maximal when no productive intervention has been carried out. Membership of local associations alone is the second-best predictor of this outcome, followed by having inherited land alone, being non-resident at the municipality where the forest property is located and the use of manual work alone for the execution of productive interventions. Therefore, formal multi-owner coordination is the preferred alternative for owners having a distant primary home (although some of them might maintain a second home locally), who cannot afford the manual and more demanding execution of productive interventions on their inherited forest land (as they tend to carry out no interventions but otherwise they have to do it manually) and without participation in local social and cultural networks (a part of bonding social capital). Other variables expressing bonding social capital do not explain the choice of collaboration (owner perception of easy agreements with neighbours for the shared execution of interventions) or have been shown to be non-significant across all options for owners (the case of frequent information sharing). As already referred to in Section 2.3, variables related to the bridging and linking dimensions of SC were also found to be not related with any of the options.

Turning to the other options, land renting to a company is mainly associated with prior forest renting experience with those kinds of contracts and no other variable, while land selling is driven mainly by not having performed any silvicultural intervention in a forest property that has been acquired only by inheritance (and not land market) by owners who perceive reaching agreements with neighbours as difficult (which adds to a weak bonding social capital).

On the other hand, our results also show that owners or their family members who take care of the forest by themselves, carry out mechanical work and have strong intracommunity ties or bonding SC (Membership of local associations alone) prefer to continue managing the land individually, rather than formal coordination (either by collaboration under FIZ or third-party coordination/land renting) or selling their land.

The selected final model specification was compared with the specification secured by backward stepwise estimation, with the former found to better fit the data and to retain more conceptually interesting variables (Appendix A-Table A1). Nevertheless, in the backward stepwise model, the plantation year had a significant effect on choosing the FIZ formal multi-owner collaborative management and land selling options (at the $5 \%$ level); all the other variables were the same as in the final model. Despite the importance attributed 
to ownership size in some studies, our results from alternative models testing the effect of this variable (Appendix A-Table A2) suggest it does not significantly affect owners' choices for different management modes and were discarded.

\subsection{Simulated Choices among Alternative Management Options for Specific Owners' Profiles}

Owners' choices for alternative management options were simulated for four owner profiles, considering their significance within our sample and in similar contexts. These profiles differ in ownership, management practices and owner attributes:

1. Investing-caring-working-land ownership was, at least partially, acquired by purchase; the owner has planted recently (after 1998) and performed at least one productive intervention; only family work has been used and forest weight on household income is relevant.

2. Outsourcing-caring-land ownership was obtained by inheritance alone, the owner has not planted recently, forest work is outsourced to a forest contractor and forest revenue is irrelevant in household income. This profile is the most represented in our sample with 34 owners.

3. Investing-renting - the owner has recently planted and some land has already been rented to a pulp company or private contractor.

4. Non-active owners-women who don't receive any revenue from the forest and are not economically active as regards their occupational status.

The mean probabilities of choosing each management option and their confidence intervals for each of the four owner profiles are presented in Figure 2.

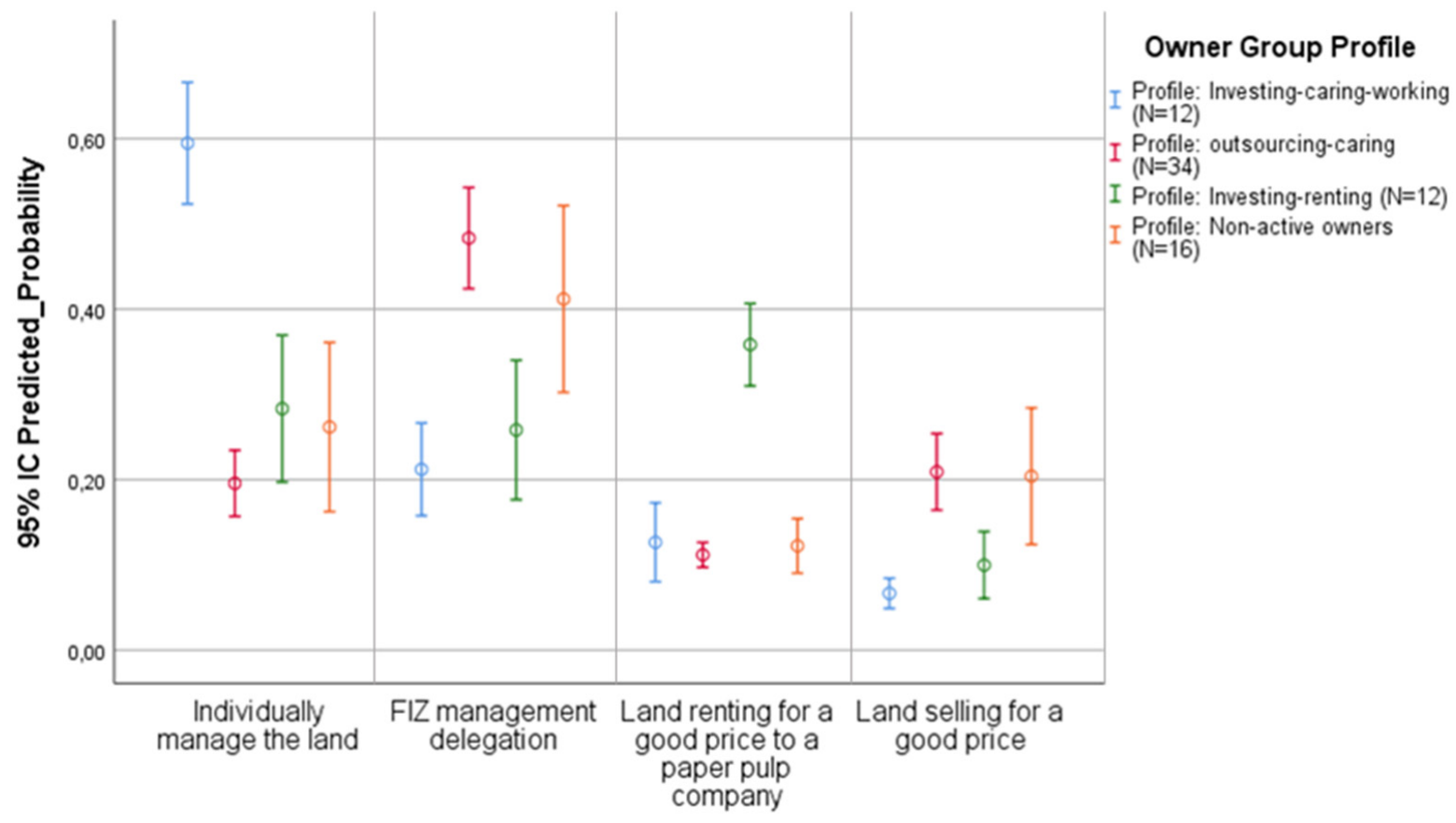

Predicted Alternative Management Options

Figure 2. Average of the predicted alternative management options for each owners' profile.

Investing-caring-working owners have a 0.60 probability of choosing to continue their independent management and a 0.20 or lower probability of choosing any one of the other alternative options. Outsourcing-caring owners, on the other hand, are most likely to choose formal multi-ownership collaboration (probability close to 0.5), i.e., management delegation to the ZIF, than any other option. Third-party coordination by an industrial corporation is the most probable (but probability barely exceeding 0.3 ) choice for Investing- 
renting owners. Finally, non-active owners seem to prefer the FIZ management delegation with a mean probability of choosing this option above 0.4 .

\section{Discussion}

We begin by exploring the factors that helped explaining the owners' choice of multiownership collaboration. Then, we compare choices for such collaboration with their alternative options, which involve markets and land rights transfer. Finally, we comment on the usefulness of this approach and its implications for the design of policies to promote landscape-level management that fit the owner profile of the target area.

\subsection{Explaining the Choice of Multi-Ownership Collaboration under Forest Intervention Zone (FIZ)}

Social capital is one of the most explored dimensions to explain owners' receptivity to collaboration, besides sociodemographic and ownership attributes $[13,29,44]$. However, according to our results, forest management practices is the most relevant dimension to explain the choice of collaboration, followed by social capital, ownership attributes and owner characteristics. Beyond this hierarchy of dimensions, the effect of several variables requires contextualization and interpretation.

Multi-ownership collaboration under FIZ is positively linked to passive management. Nonetheless, the literature concerning NIPF owners frequently makes the assumption that the lack of active management is a reflection of the owners' lack of interest in their woodlands and, then, also a reason for not participating in collaborative arrangements $[10,12,35]$. Passive management is often associated with land acquisition only through inheritance and living away from the property [14,33]. However, going through our overall model, neither land inheritance nor being a non-resident kept owners from opting for delegating management to a FIZ.

In our model, manual work is the main FMP factor associated to the collaboration alternative. Being physically demanding, time-consuming and consequently costly (its cost, in similar Portuguese contexts, even exceeds forest income, according to [45]), manual work can be taken as a proxy of harsher forest conditions, namely high slopes, lack of access by road and non-aligned stands, which hinder mechanization for more active management. Our exploratory studies suggest that the hindrances to use mechanical means, a less costly alternative, can lead to passive management. In [5] and [46], manual work appears to have the same effect if combined with family labor unavailability. Owners with management constraints, resulting from those harsher conditions or simply by living away from their forests, are willing to delegate the management of their (inherited) land to collaborative entities such as ZIFs [20]. Then this option can be viewed as a search by owners to overcome current passive management.

Regarding the place of residence, living outside the forest and abandoning the land are interchangeably taken in the literature under the umbrella concept of absenteeism [12,34]. Absenteeism is then associated with the lack of interaction and communication and then, with the lack of predisposition to cooperate [13,26]. Our model, alongside [19], showed that non-residents tend to opt for collaboration arrangements. Contrary to expectations from the literature $[10,24,26,27]$, age did not affect land management choices.

Social capital is generally expected to promote collaboration among NIPF owners $[26,35,44,47]$. However, our model reveals that strong intracommunity ties or bonding SC, referring to information sharing, trust in property neighbors or social networking, were either non-significant predictors of collaboration under FIZ, or even negatively linked to the choice of collaboration (e.g., membership of local associations led owners to choose individually managing their land), suggesting that distinct types of social capital may affect acceptance of collaboration in different ways $[37,48]$. In particular, multi-ownership collaboration may be more a matter of trust in the coordination facilitator, aimed at external representation of local interests, than intracommunity trust $[19,20]$. Therefore, on the one hand, we admit that a better design of variables expressing types of SC other than bonding SC may lead to better predictors of multi-ownership collaboration. On the other 
hand, the strength of those predictors may depend on internal institutions and governance of the collaborative arrangement itself, e.g., the extent of management delegation (partial or total) or the type of internal decision-making criteria.

Our results do not show any effect of ownership size on the choice of coordination and thus we discard the idea of a supposedly a priori unwillingness to collaborate by small owners $[10,11,27,28]$. This doesn't necessarily deny that in collaboration under FIZ the average size of participants is larger than that of non-participants; and that FIZs have a higher probability of success where average ownership size is larger [49,50]. What explains the apparent contradictions among these results are two characteristics of FIZ as multi-owner arrangements. First, for a FIZ to be approved, the aggregated area of enrolled participants should reach a minimum share of the FIZ's area and thus, for cost-effectiveness reasons, FIZ promotors tend to target larger owners in their enrolment strategy. Second, as each participant's decision-making power within many of the FIZ depends on ownership size (as in a condominium), larger owners have a higher incentive to participate [6,20]. Thus, these attributes of the FIZ arrangement-and not a supposed unwillingness to collaborate, or delegate management, by small owners-explain why FIZ participants are larger than non-participants and why it is easier to succeed in FIZ constitution where average size of ownership is larger. Therefore, we should focus more on the design of FIZ governance rules rather than on any particular attribute of small forest owners if we want to more effectively promote landscape-level management of fuels.

In sum, passive management, property size, place of residence or lack of intracommunity ties seem not to act as barriers to acceptance of collaboration. Instead, these results suggest that, when owners are unable to pursue with forest management as an economically viable activity, formal collaboration appears to them as a way out of this economically constraining context.

\subsection{Landscape-Level Management by Collaboration among Owners or by the Market}

Even though multi-ownership collaboration has been selected by almost $40 \%$ of the respondents, the majority would keep current individual management or choose other alternatives, namely selling or renting the land. The comparison among the individual management/collaboration/land rights transfer options needs to take into account both the owner-level factors of choice and the institutional characteristics of those alternatives in the local and Portuguese context.

The demand side of the land tenancy market is mainly represented by two paper pulp corporations (and possibly also a few forest contractors or loggers), which are also the only buyers in the oligopolistic timber market. These companies are landowners themselves and, through land tenancy agreements with some local NIPF owners, they promote the management coordination of all the land involved. This process is highly selective: only the best stands, as regards expected profitability and accessibility, are chosen. Establishing a tenancy contract is thus not an available option for the majority of NIPF owners, since the companies' productivity requirements are not met, or the offered rent payment is insufficient for active owners [51]. Therefore, it is not surprising that the distinguishing feature of the owners who opted for land renting is their previous or current experience with this type of agreement (investing-renting owners).

In more economically profitable areas, such as in a sample of 550 owners of eucalyptus forest across the country [50], almost half of the land may have been acquired by buying, yet, in our study setting and other similar ones in Portugal, forestland is mostly acquired through inheritance [5]. Despite the reduced movements in local land markets and the fact of Portuguese land prices being the lowest in Europe (3000 eur/ha against e.g., 33,000 eur/ha in Italy) [51], selling still seems an attractive option for non-active owners, who prefer giving up their family inheritance rather than keep paying management costs. Thus, small owners' purported attachment to their land does not seem to be an obstacle to third-party coordination or structural adjustment. These obstacles should be looked for instead in the absence of economic and market incentives that may trigger these adjustments 
from the land-demand side. On the one hand, the amount of land rented by pulp companies has not increased over the last 20 years [52]. On the other, these market-dependent modalities to promote landscape-level management are limited by factors, such as timber prices and economic risks (related with wildfires and pests), that condition "interesting investment returns" [51].

Considering the current literature, our findings lead to a non-expected outcome: wildfire-hazard reduction through fuel management coordination at the landscape-level will likely find more support from NIPF owners with passive management and living outside than from those practicing active management and living locally. Institutional and economic differences between the land rights transfer and owner collaboration alternatives are relevant to understand this outcome and seem to drive owner's choices between them $[11,18,21,24,32]$. Under land renting, the owner accepts a commitment of variable duration (e.g., 24 years) against a rent, whereas under FIZ delegation the duration of the commitment is somewhat undefined and what is at stake is not whether there is a sufficient compensation to the owner, but the fact that it provides a way to overcome a situation of underinvestment. There is, however, an expectation that the FIZ would be financed by public policies to overcome the lack of profitability of any investment in better management.

This helps to explain why investing-caring-working NIPF owners, who execute forest management practices, work actively on the property and expand ownership by other means rather than inheritance alone, are not likely to depart from individual management, as they are able to assure economically viable management under current circumstances. Simultaneously, the effort involved when enrolling in a FIZ (e.g., time spent on meetings, paperwork, following a common forest management plan) and the undefined character of some particular advantages and obligations may lead them to negatively perceive this option. In contrast, for non-active owners, the multi-ownership collaboration modality carries an expectation of solution for their economic constraints that may lead them to overcome current underinvestment and non-active management.

\subsection{Policy Implications for Promoting Landscape-Level Management and Wildfire-Hazard Reduction}

There are some relevant implications of our results for the design of policies aimed at promoting sustainable fuel load reduction at the landscape-level.

First, the promotion of the formal multi-owner collaboration arrangements is not, in general, easy [12]. It is particularly difficult when it has the ambition of reaching landscapelevel management. The effectiveness of cross-boundary collaboration under FIZ involves several hundred of owners, in our case study and in the majority of Portuguese rural areas [4], whose willingness to collaborate is hardly the same for all as their immediate interests differ: some have nothing to lose (non-active owners), while others may lose (investing-caring-working). For example, for these latter, who often hold better land, the extension of fuel management to poorer land, through collaborative management, or delivering productive land for fuel breaks, may not be seen as good business in the short run, since the benefits of hazard reduction are deferred over time, uncertain and shared with other owners, whereas the direct and opportunity costs involved in these interventions are immediate and certain [38].

Second, comparison with other non-collaborative alternatives emphasizes how the internal governance and external policy support to multi-owner collaboration are essential in defining the benefits and costs for each owner type and should not be ignored in policies aimed at effectiveness $[3,53,54]$. The scope of FIZ executive competences (managing only common parts, such as fuel-breaks, as in a condominium, or also stand-level forest management, that is: FIZ with partial or total delegation of management, respectively), the internal voting rule ("one person, one vote" or depending on the ownership area) and the external funding criteria (depending on the FIZ area alone or including also the number of FIZ enrolled owners), among others, are decisive for defining owners' benefits and costs and consequently their interest in collaboration [20]. The type of governance 
arrangements establishes the type of owners who will be more willing to collaborate. Thus, different owner-type patterns, in each area, will require locally adapted internal and external governance arrangements, as shown by the uptake predictions made with our model for different owner types.

Third, land and tenancy markets, as well as public policies, have largely been unable to contribute to the adjustment of the forest ownership structure in Portugal. That absence of adjustment contrasts with the increase in average size of Portuguese farms over the last 30 years [55,56]. Farm structural change is very well documented in post-Second World War Europe and was promoted by public policies together with the more invisible hand of market mechanisms $[55,57,58]$. The supply side of land and tenancy markets, which mostly correspond to small owners, has been often blamed for hindering structural adjustment in Portugal. However, since our respondents do not seem adverse to rent or sell their land, our results suggest that the demand side in these markets should instead be seen as the weak side, because demand for land would require that land management options exist that are sufficiently profitable to deliver a positive economic rent.

Fourth, although multi-owner collaboration may be complex, it is the best path for promoting public interest, in many contexts where non-active and outsourcing-caring owners prevail, as shown by our predictions. Moreover, in Portugal, policies to promote market-dependent mechanisms to achieve ownership adjustments have failed where they were mostly needed $[57,59]$. Investment dedicated to implement multi-ownership collaborative arrangements under FIZ is also expected to yield a more positive contribution for the development of declining rural areas, by the promotion of social and economic ties between the numerous owners involved, which exist even in territories as economically marginal as Alvares [19].

\section{Conclusions}

Modeling owners' choices between delegating management under a multi-ownership collaboration, renting or selling the land has revealed the most important owner-level factors affecting those choices and allowed us to explore key context factors. A large majority of owners opted for either delegating management on a multi-owner arrangement or transferring land rights through renting or selling the land, whereas only one third preferred to keep the current situation of individually managing their forest land. Therefore, there is not an a priori generalized unwillingness of owners to align themselves with policy strategies to promote management at the landscape level.

The association of passive management with a preference for management delegation and the fact that smaller owners are not less prone to delegate management were surprising, given their opposition to what could be deduced from the literature. This invited us to look more to context variables, such as the economic constraints resulting from harsher conditions faced by passive-management owners, or the governance rules of legally defined multi-owner arrangements such as FIZ, when discussing the implementation deficit of policies aimed at promoting multi-owner collaboration.

The potential of land right transferring through the tenure or land markets was revealed to be weak as a generalized solution to promote landscape-level management. Surprisingly this was also not due to a generalized land attachment by (particularly small) owners, which would block land supply, but seems more related to the weakness of land demand in the aforementioned markets. Both of these results and discussions underlined the importance of studying owner-level as well as context factors, such as local constraints on land productivity, slope-related management costs, governance arrangements and land market conditions, when it comes to understanding in a systemic way the possibilities for policy action.

Recognizing the importance of studying owner-level factors to inform policy, we used our estimated models of owner's choice to predict choices made by particular owner profiles. Different owner profiles were revealed to make quite different choices, which supports our hypothesis that the best policy depends on the local owner profiles. 
This study also provides a method to select the policy strategy (multi-ownership collaboration, coordination by third party, or structural adjustment) best fitting a particular area with a specific pattern of owner profiles. Because they are context-dependent, best policy strategies are not transferrable across areas with different contexts and different patterns of owner profiles. For example, in areas where large-scale private ownership and better land prevail and wildfire-hazard is lower, the benefits of multi-owner collaboration would be much lower. While predictions of uptake by owners of different options are also not transferable to areas with different patterns of owner profiles, our model can be transferred to yield these predictions in a different area, provided that the range of variation of the owner-level factors in that area is not completely outside the data we used for model estimation. These predictions can then be used to provide support to select the best policy strategy in that area. More generalized models can be estimated in future research based on broader data sets, including wider variation of owner-level factors and new factors within the set of dimensions included in the framework developed in this study. Broader data sets including significant context variation could also be used to estimate the effects of context variables.

Author Contributions: Conceptualization, A.M., A.N., J.L.S. and M.J.C.; methodology, A.M., A.N., J.L.S. and M.J.C.; validation, A.M., A.N., J.L.S. and M.J.C.; formal analysis, A.M., A.N., J.L.S. and M.J.C.; investigation, A.M., A.N., J.L.S. and M.J.C.; data curation, A.M.; writing-original draft preparation, A.M., A.N., J.L.S. and M.J.C.; writing-review and editing, A.M., A.N., J.L.S. and M.J.C.; visualization, A.M., A.N., J.L.S. and M.J.C.; supervision, M.J.C. and J.L.S.; project administration, A.M. All authors have read and agreed to the published version of the manuscript.

Funding: The authors would like to acknowledge the support of the Fundação para a Ciência e Tecnologia (FCT) by providing the Ph.D. fellowship (PDBD/113930/2015) through the Climate Change and Sustainable Development Policies PhD Program. FCT also supported this research, through the project "People and Fire (FCT-PCIF/AGT/0136/2017), which also paid for the publication fees. The fieldwork was funded by the journal "Observador".

Data Availability Statement: Data is not available due to confidentiality and privacy issues given the extremely small size of the study area and relatively small number of forest owners in the study area, that would made some of them identifiable even if the data were anonymous.

Acknowledgments: We are grateful to all colleagues and people from the Alvares community who helped us during the fieldwork, in particular to all the forest owners who participated in our survey. We are also grateful for the useful and constructive comments from the anonymous reviewers which have improved the quality of the manuscript.

Conflicts of Interest: The authors declare no conflict of interest. The funders had no role in the design of the study; in the collection, analyses, or interpretation of data; in the writing of the manuscript, or in the decision to publish the results.

\section{Appendix A}

Table A1. Backward stepwise MNL model.

\begin{tabular}{|c|c|c|c|c|c|c|c|c|c|}
\hline & \multicolumn{3}{|c|}{$\begin{array}{l}\text { FIZ Management } \\
\text { Delegation }\end{array}$} & \multicolumn{3}{|c|}{$\begin{array}{l}\text { Land Renting for a Good Price } \\
\text { to a Paper Pulp Company }\end{array}$} & \multicolumn{3}{|c|}{$\begin{array}{l}\text { Land Selling for } \\
\text { a Good Price }\end{array}$} \\
\hline & $\beta$ & & $\operatorname{Exp}(\beta)(\#)$ & $\beta$ & & $\operatorname{Exp}(\beta)(\#)$ & $\beta$ & & $\operatorname{Exp}(\beta)(\#)$ \\
\hline Intercept & 0.60 & & & -0.63 & & & 0.74 & & \\
\hline$[\mathrm{OF}]$ Non-primary Sector Income & 0.40 & & 1.49 & 0.85 & $(*)$ & 2.34 & -0.96 & & 0.38 \\
\hline$[\mathrm{OF}]$ Non-resident & 1.11 & $* * *$ & 3.02 & 0.26 & & 1.29 & 0.43 & & 1.53 \\
\hline [SC] Bridging Capital & -0.90 & * & 0.41 & 0.00 & & 1.00 & 0.45 & & 1.56 \\
\hline [FMP] Last Planted after 1998 & -0.74 & * & 0.48 & 0.39 & & 1.48 & -1.23 & $* *$ & 0.29 \\
\hline [FMP] At Least One PI & -0.86 & $(*)$ & 0.42 & -1.48 & $* *$ & 0.23 & -1.56 & $* * *$ & 0.21 \\
\hline [FP] With Renting Lease & 0.62 & & 1.86 & 1.65 & $* *$ & 5.20 & -0.03 & & 0.97 \\
\hline
\end{tabular}


Table A1. Cont.

\begin{tabular}{|c|c|c|c|c|c|}
\hline & \multicolumn{2}{|c|}{$\begin{array}{c}\text { FIZ Management } \\
\text { Delegation }\end{array}$} & $\begin{array}{l}\text { Land Renting for a Good Price } \\
\text { to a Paper Pulp Company }\end{array}$ & \multicolumn{2}{|c|}{$\begin{array}{l}\text { Land Selling for } \\
\text { a Good Price }\end{array}$} \\
\hline & $\beta$ & $\operatorname{Exp}(\beta)(\#)$ & $\beta \quad \operatorname{Exp}(\beta)(\#)$ & $\beta$ & $\operatorname{Exp}(\beta)(\#)$ \\
\hline Model Statistics & & $\begin{array}{r}\text { Likelihoo } \\
\text { Goodness o }\end{array}$ & $\begin{array}{l}\text { Model Fit: AIC }=533 . \text { BIC }=604 \\
-2 \text { Log Likelihood = } 491 . \\
\text { ratio test Qui2 (df:18)= 66. Sig. }= \\
\text { it: Pearson Qui2 (df: } 603)=646 . \text { Si } \\
\text { McFadden Pseudo R2 = 0.117 } \\
\text { Number of observations: } 220\end{array}$ & $0(<$ & \\
\hline
\end{tabular}

Note A.1.1: The reference category is "Individually managing the land"; Note A.1.2: Significant at $1 \%{ }^{* * *} ; 2.5 \%$ ** $5 \% *, 10 \%\left(^{*}\right)$. Indicated in Bold until 5\%. Note A.1.3: italic variable that remained on the model obtained by backward stepwise when comparing with the overall model. Note A.1.4: (\#) for readability purposes in the case of significant negative $\operatorname{Exp}(\beta)$ values we also present in brackets the equivalent odd ratio value for the inverse of the variable, as it would have a positive (influencing factor) effect.

Table A2. Alternative MNL models including different ownership size variables (discarded).

\begin{tabular}{|c|c|c|c|c|c|c|c|c|c|c|c|}
\hline \multirow{2}{*}{ Model } & \multicolumn{3}{|c|}{ Model Fit } & \multicolumn{3}{|c|}{$\begin{array}{l}\text { Likelihood Ratio } \\
\text { Test }\end{array}$} & \multicolumn{3}{|c|}{ Goodness of Fit } & \multirow{2}{*}{$\begin{array}{l}\text { McFadden } \\
\text { Pseudo R2 }\end{array}$} & \multirow{2}{*}{$\begin{array}{l}\text { Number of } \\
\text { Observations }\end{array}$} \\
\hline & AIC & BIC & $-2 \mathrm{LL}$ & Qui2 & df & Sig. & $\begin{array}{l}\text { Pearson } \\
\text { Qui2 }\end{array}$ & df & Sig. & & \\
\hline Forest and Property [FP] & 58 & 89 & 40 & 21 & 6 & 0.002 & 0.39 & 3 & 0.942 & 0.038 & 221 \\
\hline $\begin{array}{c}\text { Forest and Property [FP]+ } \\
\text { Ownership size }\end{array}$ & 357 & 397 & 333 & 24 & 9 & 0.004 & 284 & 258 & 0.127 & 0.046 & 205 \\
\hline $\begin{array}{l}\text { Forest and Property }[\mathrm{FP}]+\text { Ownership } \\
\text { size above } 10 \text { ha }\end{array}$ & 91 & 131 & 67 & 24 & 9 & 0.000 & 9 & 12 & 0.706 & 0.045 & 205 \\
\hline $\begin{array}{c}\text { Forest and Property }[\mathrm{FP}]+\text { Ownership } \\
\text { size above } 4 \text { ha^ }\end{array}$ & 86 & 126 & 62 & 27 & 9 & 0.001 & 6 & 12 & 0.903 & 0.051 & 205 \\
\hline $\begin{array}{c}\text { Forest and Property [FP] + Ownership } \\
\text { Size below } 4 \text { ha^ and Ownership Size } \\
\text { between } 4 \text { and } 10 \text { ha }^{\wedge}\end{array}$ & 120 & 170 & 90 & 30 & 12 & 0.003 & 20 & 21 & 0.490 & 0.057 & 205 \\
\hline
\end{tabular}

Note A.2.1: ^ this variable was not statistically significant (wald) when added to the model, although it was adequately fitted statistically.

\section{References}

1. Moreira, F.; Viedma, O.; Arianoutsou, M.; Curt, T.; Koutsias, N.; Rigolot, E.; Barbati, A.; Corona, P.; Vaz, P.; Xanthopoulos, G.; et al. Landscape-wildfire interactions in southern Europe: Implications for landscape management. J. Environ. Manag. 2011, 92, 2389-2402. [CrossRef] [PubMed]

2. Fernandes, P.M. Fire-smart management of forest landscapes in the Mediterranean basin under global change. Landsc. Urban Plan. 2013, 110, 175-182. [CrossRef]

3. OECD. Providing Agri-Environmental Public Goods through Collective Action; Organisation for Economic Co-operation and Development: Paris, France, 2013.

4. Canadas, M.J.; Novais, A.; Marques, M. Wildfires, forest management and landowners' collective action: A comparative approach at the local level. Land Use Policy 2016, 56, 179-188. [CrossRef]

5. Baptista, F.O.; Santos, R.T. Os Proprietários Florestais: Resultados de um Inquérito; Celta: Oeiras, Portugal, 2005.

6. Pulla, P.; Schuck, A.; Verkerk, P.; Lassere, B.; Marchetti, M.; Green, T. Mapping the Distribution of Forest Ownership in Europe; European Forest Institute: Joensuu, Finland, 2013.

7. FAO; UNECE. Who Owns Our Forests? Forest Ownership in the ECE Region; United Nations publication issued by the Economic Commission for Europe (ECE); Economic Commission for Europe: Geneva, Switzerland, 2020.

8. Feliciano, D.M.S.; Alves, R.; Mendes, A.; Ribeiro, M.; Sottomayor, M. Forest Land Ownership Changes in Portugal; European Forest Institute Central-East and South-East European Regional Office: Vienna, Austria, 2015.

9. Rickenbach, M.G.; Kittredge, D.B.; Dennis, D.; Stevens, T. Ecosystem management: Capturing the concept for woodland owners. J. For. 1998, 96, 18-24.

10. Jacobson, M.G.; Abt, R.C.; Carter, D.R. Attitudes toward joint forest planning among private landowners. J. Sustain. For. 2000, 11, 95-112. [CrossRef]

11. Klosowski, R.; Stevens, T.; Kittredge, D.; Dennis, D. Economic incentives for coordinated management of forest land: A case study of southern New England. For. Policy Econ. 2001, 2, 29-38. [CrossRef]

12. Kittredge, D.B. The cooperation of private forest owners on scales larger than one individual property: International examples and potential application in the United States. For. Policy Econ. 2005, 7, 671-688. [CrossRef] 
13. Fischer, A.P.; Klooster, A.; Cirhigiri, L. Cross-boundary cooperation for landscape management: Collective action and social exchange among individual private forest landowners. Landsc. Urban Plan. 2019, 188, 151-162. [CrossRef]

14. Weiss, G.; Lawrence, A.; Hujala, T.; Lidestav, G.; Nichiforel, L.; Nybakk, E.; Quiroga, S.; Sarvasová, Z.; Suarez, C.; Živojinović, I. Forest ownership changes in Europe: State of knowledge and conceptual foundations. For. Policy Econ. 2019, 99, 9-20. [CrossRef]

15. Rickenbach, M.G.; Guries, R.P.; Schmoldt, D.L. Membership matters: Comparing members and non-members of NIPF owner organizations in southwest Wisconsin, USA. For. Policy Econ. 2006, 8, 93-103. [CrossRef]

16. Van-Gossum, P.; De-Mayer, W. Performance of forest groups in achieving multifunctional forestry in Flanders. Small-Scale For. Econ. Manag. Policy 2006, 5, 19-36.

17. Schulte, L.A.; Rickenbach, M.; Merrick, L.C. Ecological and economic benefits of cross-boundary coordination among private forest landowners. Landsc. Ecol. 2008, 23, 481-496. [CrossRef]

18. Gass, R.; Rickenbach, M.; Schulte, L. Forest management on parcelized landscapes: Private forest owners assessments of cross-boundary alternatives. In Proceedings of the Interconnecting Forests, Science and People, IUFRO, Galway, Ireland, 18-23 June 2006; Volume 3, pp. 93-102.

19. Canadas, M.J.; Novais, A. Forest owners and fuels management coordination. When neighbours' actions matter. Scand. J. For. Res. 2019, 34, 67-77. [CrossRef]

20. Canadas, M.J.; Novais, A.; Marques, M. Proprietários Florestais, Políticas e Territórios-Incêndios e a Gestão do Espaço Rural; Animar: Lisboa, Portugal, 2014.

21. Stevens, T.H.; Dennis, D.; Kittredge, D.; Rickenbach, M. Attitudes and preferences toward co-operative agreements for management of private forestlands in the North-eastern United States. J. Environ. Manag. 1999, 55, 81-90. [CrossRef]

22. Jacobson, M.G. Ecosystem management in the Southeast United States: Interest of forest landowners in joint management across ownerships. Small-Scale For. Econ. Manag. Policy 2002, 1, 71-92. [CrossRef]

23. Gass, R.J.; Rickenbach, M.; Schulte, L.A.; Zeuli, K. Cross-boundary coordination on forested landscapes: Investigating alternatives for implementation. Environ. Manag. 2009, 43, 107-117. [CrossRef]

24. Finley, A.O.; Kittredge, D.B.; Stevens, T.H.; Schweik, C.M.; Dennis, D.C. Interest in cross-boundary cooperation: Identification of distinct types of private forest owners. For. Sci. 2006, 52, 10-22.

25. McGill, D.W.; Grushecky, S.T.; Moss, S.; Pierskalla, C.; Schuler, A. Landowner willingness to engage in long-term timber leases in West Virginia, USA. Small-Scale For. 2008, 7, 105-116. [CrossRef]

26. Fischer, A.P.; Charnley, S. Risk and cooperation: Managing hazardous fuel in mixed ownership landscapes. Environ. Manag. 2012, 49, 1192-1207. [CrossRef]

27. Ferranto, S.; Huntsinger, L.; Getz, C.; Lahiff, M.; Stewart, W.; Nakamura, G.; Kelly, M. Management without borders? A survey of landowner practices and attitudes toward cross-boundary cooperation. Soc. Nat. Resour. 2013, 26, 1082-1100. [CrossRef]

28. Fischer, A.P.; Kline, J.D.; Charnley, S.; Olsen, C. Identifying policy target groups with qualitative and quantitative methods: The case of wildfire risk on nonindustrial private forest lands. For. Policy Econ. 2013, 25, 62-71. [CrossRef]

29. Lind-Riehl, J.; Jeltema, S.; Morrison, M.; Shirkey, G.; Mayer, A.L.; Rouleau, M.; Winkler, R. Family legacies and community networks shape private forest management in the western Upper Peninsula of Michigan (USA). Land Use Policy 2015, 45, 95-102. [CrossRef]

30. Herbohn, J. Small-scale forestry: Is it simply a smaller version of industrial (large-scale) multiple use forestry? In Proceedings of the Small-Scale Forestry Conference Proceedings, IUFRO, Galway, Ireland, 18-23 June 2006; pp. 158-163.

31. Novais, A.; Canadas, M.J. Understanding the management logic of private forest owners: A new approach. For. Policy Econ. 2010, 12, 173-180. [CrossRef]

32. Deuffic, P.; Sotirov, M.; Arts, B. Your policy, my rationale. How individual and structural drivers influence European forest owners' decisions. Land Use Policy 2018, 79, 1024-1038. [CrossRef]

33. Ficko, A.; Lidestav, G.; Dhubháin, Á.N.; Karppinen, H.; Zivojinovic, I.; Westin, K. European private forest owner typologies: A review of methods and use. For. Policy Econ. 2019, 99, 21-31. [CrossRef]

34. Beighley, M.; Hyde, A.C. Portugal Wildfire Management in a New Era: Assessing Fire Risks, Resources and Reforms; Centro de Estudos Florestais-Instituto Superior de Agronomia/Universidade de Lisboa: Lisboa, Portugal, 2018; 59p.

35. Górriz-Mifsud, E.; Donazar, L.O.; Eseverri, E.M.; Govigli, V.M. The challenges of coordinating forest owners for joint management For. Policy Econ. 2019, 99, 100-109. [CrossRef]

36. Butler, B.J.; Caputo, J.; Robillard, A.L.; Sass, E.M.; Sutherland, C. One Size Does Not Fit All: Relationships between Size of Family Forest Holdings and Owner Attitudes and Behaviors. J. For. 2021, 119, 28-44. [CrossRef]

37. López-Gunn, E. Groundwater governance and social capital. Geoforum 2012, 43, 1140-1151. [CrossRef]

38. Santos, J.L.; Martins, A.; Novais, A.; Canadas, M.J. A choice-modelling approach to inform policies aimed at reducing wildfire hazard through the promotion of fuel management by forest owners. Forests 2021, 12, 403. [CrossRef]

39. Pereira, J.M.C.; Benali, A.; Sá, A.C.L.; Le Page, Y.; Barreiro, S.; Rua, J.; Tomé, M.; Santos, J.M.L.; Canadas, M.J.; Martins, A.P.; et al. Alvares-um Caso de Resiliência ao Fogo (Relatório Técnico); Instituto Superior de Agronomia: Lisboa, Portugal, 2019.

40. Verde, J.C.; Zêzere, J.L. Assessment and validation of wildfire susceptibility and hazard in Portugal. Nat. Hazards Earth Syst. Sci. 2010, 10, 485-497. [CrossRef]

41. Woolcock, M. The place of social capital in understanding social and economic outcomes. Can. J. Policy Res. 2001, 2, 11-17.

42. Jaccard, J. Interaction Effects in Logistic Regression; Sage: Thousand Oacks, CA, USA, 2001. 
43. Borooah, V.K. Logit and Probit: Ordered and Multinomial Models; Sage: Thousand Oacks, CA, USA, 2002.

44. Górriz-Mifsud, E.; Secco, L.; Pisani, E. Exploring the interlinkages between governance and social capital: A dynamic model for forestry. For. Policy Econ. 2016, 65, 25-36. [CrossRef]

45. DGRF. Estratégia Nacional Para as Florestas; Direção Geral de Recursos Florestais: Lisboa, Portugal, 2006.

46. Canadas, M.J.; Novais, A. Bringing local socioeconomic context to the analysis of forest owners' management. Land Use Policy 2014, 41, 397-407. [CrossRef]

47. Kittredge, D.B.; Rickenbach, M.G.; Knoot, T.G.; Snellings, E.; Erazo, A. How personal connections shape decisions about private forest use. N. J. Appl. For. 2013, 30, 67-74. [CrossRef]

48. Bihari, M.; Ryan, R. Influence of social capital on community preparedness for wildfires. Landsc. Urban Plan. 2012, 106, 253-261. [CrossRef]

49. Deus, E. A Implementação do Conceito Zona de Intervenção Florestal em Portugal: O Caso do Concelho de Mação; Faculdade de Letras/Universidade de Coimbra: Coimbra, Portugal, 2010.

50. Reis, P.; Novais, A.; Canadas, M.J.; Amaral, M. Replantação do Eucaliptal: Aspectos Socioeconómicos; ISA: Lisboa, Portugal, 2018.

51. Pra, A.; Masiero, M.; Barreiro, S.; Tomé, M.; De Arano, I.M.; Orradre, G.; Onaindia, A.; Brotto, L.; Pettenella, D. Forest plantations in Southwestern Europe: A comparative trend analysis on investment returns, markets and policies. For. Policy Econ. 2019, 109, 102000. [CrossRef]

52. CELPA. Boletim Estatístico; Associação da Indústria Papeleira: Lisboa, Portugal, 2018.

53. Poteete, A.; Ostrom, E. Fifteen years of empirical research on collective action in natural resource management: Struggling to build large-N databases based on qualitative research. World Dev. 2008, 36, 176-195. [CrossRef]

54. Ratner, B.; Meinzen-Dick, R.; May, C.; Haglund, E. Resource conflict, collective action and resilience: An analytical framework. Int. J. Commons 2013, 7, 182-208. [CrossRef]

55. Arnalte-Alegre, E.; Ortiz-Miranda, D. The "Southern Model" of European agriculture revisited: Continuities and dynamics. Res. Rural. Sociol. Dev. 2013, 19, 37-49.

56. INE. Recenseamento Agrícola 2019-Resultados Preliminares; Instituto Nacional de Estatística: Lisboa, Portugal, 2020.

57. Baptista, F.O. A questão da terra. In Terra e Tecnologia: Século e Meio de Debates e Políticas de Emparcelamento; Baptista, F., Ed.; Celta: Lisboa, Portugal, 2005; pp. 193-220.

58. Arnalte, E. Questões sobre a evolução das estruturas agrárias. O caso de Espanha. Agricultura, Terra, Rural: Tempos de Mudança; Baptista, F., Ed.; 100LUZ: Castro Verde, Portugal, 2021; pp. 175-196.

59. Radich, M.C.; Baptista, F. Terra e Agricultura: Século XX; 100LUZ: Castro Verde, Portugal, 2021; 389p. 